\title{
The Effect of Internal Control on the Competitive Advantage of the Bank
}

\author{
Bader Mustafa Mahmoud AlSharif ${ }^{1} \&$ Zaher Abdel Fattah Al-Slehat $^{1}$ \\ ${ }^{1}$ Business Economics Department, Faculty of Business, Tafila Technical University, Tafila, Jordan \\ Correspondence: Bader Mustafa Mahmoud AlSharif, Business Economics Department, Faculty of Business, \\ Tafila Technical University, Tafila, Jordan. E-mail: bader.alsharif99@gmail.com
}

Received: March 24, 2019

doi:10.5539/ijbm.v14n9p91
Accepted: April 30, 2019

Online Published: August 5, 2019

\begin{abstract}
The current study aims at identifying the effect of internal control on the competitive advantage of the bank with its three dimensions (administrative, financial and operational control) on the competitive advantage of the bank. The analytical, descriptive and deductive approaches were applied in the current study. The current study is a field study in terms of nature and explanatory in terms of purpose because it aims at revealing the cause and effect between internal control and competition. In terms of time horizon, it is a cross-sectional study applied on a sample that composes of all employees of the internal control department in banks.137 questionnaires were distributed to the employees of Internal Control Department of the banks; 106 of which were retrieved, with a recovery rate of $77.36 \%$. Statistical Package for the Social Sciences (SPSS) was used to test the hypotheses of the study and to answer its questions through Simple \& Multiple Linear Regression. Among the most important results of the study was a statistically significant effect of internal control (administrative, financial and operational control) on the competitive advantage of the bank. The study recommended the establishment of an efficient internal control department through linking it to the director of audit or the general manager, and the feedback of such department shall be taken into consideration and the reasons of such feedback shall be identified without delay in order to reduce the risks, increase profits and raise the level of performance, and thus, increase the competitive advantage of the bank.
\end{abstract}

Keywords: internal control, administrative, financial and operational control, competitive advantage, bank.

\section{Introduction}

\subsection{Introduce the Problem}

The banking sector has witnessed a great development in recent decades, especially in the size, quality and speed of services provided. This has led to the intensification of competition with the external environment in order that the banks attract as many customers as possible. Therefore, banks had to establish a sound internal control system according to policies, and to comply with several international standards in the field of internal control systems. Therefore, there is a great role for the internal control system in reducing the risks facing the bank, increasing the quality of services provided and maintaining the assets of the bank, and then increase profits. In light of the economic openness, independence of decision-making and the economic freedom experienced by customers, this has led to the creation of strong competition among banks based on the quality of services provided and the volume of profits and the ability of the bank to reduce risks of all kinds of risks, and thus, the ability of the bank to protect its assets what leads to the increased competitive advantage of the bank (Abdul Razzaq, 2010, p. 70).

The Bank's competitive advantage is based on the quality of services provided, increased profits and reduced risk. Given the increasing importance of banks and the challenges they face due to the increasing development of information technology, banks should focus on internal control, which in turn reduces risks, increases profitability, increases the quality of services provided, and thus, increases the competitive advantage of the bank. Hence, the problem of the study lies in answering the main question:

What is the impact of the internal control (administrative, financial and operational control) on the competitive advantage of the bank? 


\subsection{Objectives of the Study}

The subject of internal control is the concern of senior management in financial and banking institutions. This is due to the importance of the internal control function which supports decision making, providing high quality services with high profit and less risk, and then entering the competition market with full force.

\subsection{On this Basis, the Objectives of the Current Study Are Summarized As Follows:}

1) To identify the dimensions of internal control.

2) To identify the effect of internal control on the competitive advantage of the bank with its three dimensions (administrative, financial and operational control) on the competitive advantage of the bank.

\subsection{Importance of the Study}

1) Theoretical importance

The importance of the current study stems from the importance of the internal control function in the financial and banking institutions by achieving security and stability in banking operations through compliance with law, policies and procedures adopted by the bank.

\section{2) Practical importance}

The importance of the current study stems from the importance of the banking sector and its great role in the economy. Therefore, the role of banking control should be enhanced to ensure that risks are avoided or minimized, thus enhancing the entity's competitive position in the market.

\subsection{Literature Review}

1) The study aimed to evaluate the role of internal auditor in improving the internal control system of accounting information systems in the insurance companies operating in Yemen. In order to achieve the objective of the study, a questionnaire was distributed to 35 internal auditors. The results of the study showed a significant impact of the internal auditor's role in improving the internal control system of accounting information systems in the insurance companies operating in Yemen through his experience, efficiency, integrity and neutrality. The study recommended that insurance companies should give the internal auditors the full powers that assist them in carrying out the examination and evaluation of the control systems periodically to discover deficiencies in the control procedures that help the fraud to falsify financial records and statements. This study helps identify the factors contributing to the improvement and development of the internal control system. (Al-Jabiri, 2014)

2) The aim of this study was to evaluate the internal control system of establishments that use information technology. The study has relied on a questionnaire distributed to a sample of 35 employees in the Yemeni Audit Department. The study found that there were problems with the evaluation of the internal control system under using information technology $(66 \%)$, and that the requirements of the audit offices to evaluate the internal control were not available $(76 \%)$. The study recommended that the auditor should be familiar with the nature of the control over applications in order to be able to master the internal control using the information technology.

This study helps examine the status of the internal control system and to benefit from the items of the questionnaire. (Al-Rabidi, 2012)

3) This study aimed at determining the importance of internal control and the necessity of adapting it to the development of the use of information technology, and determining the impact of such adaption on the reliability of financial statements in Libyan commercial banks. In order to achieve the objective of the study, a questionnaires was distributed to the sample of the study, consisting of (122) financial managers, internal auditors and computer employees in the banks. The results of the study showed a high level of adaptation of the internal control systems with the development of the use of information technology in the Libyan commercial banks to meet the challenges resulting from this development. The results of the study showed that there was an average level of adaptation of the internal control systems with the development of the use of information technology in the Libyan commercial banks with the regulations for obtaining reliable financial statements. There was also an average level of adequacy of the internal control systems with the development of the use of information technology in Libyan commercial banks with the regulations of such banks. The study recommended the necessity of complying with internal control instructions by Libyan commercial bank employees in order to improve the reliability of the financial statements. This study helps determine the extent to which commercial banks comply with internal control standards. (Al-Sha'ibi, 2011)

4) The study aimed to identify the internal control and its methods, and to determine its role in achieving banking safety under the electronic accounting information system. In order to achieve the objectives of the 
study, a questionnaire was distributed to (10) private commercial banks in the city of Sulaymaniyah.

The results of the study showed the need for effective internal control to keep abreast of the developments in the information technology environment in such a way as to facilitate integration with the information, administrative and financial systems. The study recommended the establishment of an internal control system that provides risk assessment and has concern with information and communication systems, and control activities and includes all operations of the bank. This study helps identify the role of internal control in banking sector in the presence of an electronic accounting information system, and to identify its characteristics, features and weaknesses, which supports the theoretical framework of the study. (Hildani \& Al-Ghalban, 2010)

5) The study aimed to identify the need for a comprehensive control system in Islamic banks that can meet the challenges of assets and capital. To achieve the objectives of the study, a questionnaire was distributed to (40) employees in the banks of Hadramout governorate. The results of the study showed that all banks had an internal control system. Moreover, the study did not find any statistically significant differences in the degree of application of internal control system by Islamic and traditional banks. The study recommended the need to more activate the role of internal control by finding a central body to play such role. This study helps identify the role played by the internal controls in Islamic banks in order to determine the obstacles facing the assets and capital. (Al-Na'sani, 2010)

6) The aim of the study was to assess the impact of computer use on the internal control systems in the banks operating in Gaza Strip. In order to achieve the objectives of the study, a questionnaire was distributed to (105) computer and control employees in banks operating in Gaza Strip. The results of the study showed that the banks operating in Gaza Strip apply the control procedures at a high level despite the weakness in the application of some of them. The study recommended the need to exploit the available computer programs in the application of control procedures. This study helps determine the importance of internal controls in banking institutions in light of the reliance on the potentials available in computer. (Mosleh, 2007)

7) The study aimed to identify a pilot test for Cubit as an internal control framework for information technology. The study examined the conceptual model of the internal control framework (Cubit) as applied to the audit settings including the processes, compliance and auditing settings. The results indicated that Cubit model predicts that the auditor's behavior in this area is related to assistance request and provision. It has also pointed out that information systems and auditing are areas that do not validate the internal control theory. This study helps review a pilot test of Cubit as a framework for internal control of information technology (Tuttle \& Vandervelde, 2006).

8) The study aimed to verify the credibility of internal control over the hours and fees of auditing the information system, based on data obtained from (60) clients of a global audit company. The results showed that the internal control system effectively reduces the efforts of information system control assessment and reduces evaluation fees. The results confirmed that the organization's or company's keenness to adopt modern technology is necessary to assess the credibility of the performance of each of the control systems and systems under control, where the techniques for assessing the credibility of performance can be considered as vital and necessary for the company. This study helps refer to the dimensions of the internal control system (Diagle et al., 2005).

\subsection{What Distinguishes the Current Study from Previous Studies}

All previous studies dealt with internal control independently or studied its effect on quality, but did not address its effect on the competitive advantage of the bank. The current study is distinguished from all previous studies in that it has dealt with identifying the effect of internal control on the competitive advantage of the bank, as competition has a significant impact on the survival of banks in the banking market.

After you have introduced the problem and have developed the background material, explain your approach to solving the problem. In empirical studies, this usually involves stating your hypotheses or specific question and describing how these were derived from theory or are logically connected to previous data and argumentation. Clearly develop the rationale for each. Also, if you have some hypotheses or questions that are central to your purpose and others that are secondary or exploratory, state this prioritization. Explain how the research design permits the inferences needed to examine the hypothesis or provide estimates in answer to the question.

\section{Theoretical Framework}

\subsection{The Concept of Internal Control (Al-Wardat, 2006, p. 143)}

Internal control is an important part of the organization's management. Internal control includes plans, methods and procedures used to achieve the objectives and thus supports performance-based management. Internal control is a safety valve for the protection of assets and the prevention of errors and counterfeiting. Internal 
control means that operations are carried out by a team of employees through the following:

1) Dependence on financial statements.

2) Commitment to the application of laws and legislation.

3) Efficiency and effectiveness of operations.

\subsection{Types of Internal Control}

1) Administrative control is the organizational plan, procedures and decision-making processes leading to the administrative licensing of operations. This license is an administrative function directly related to the responsibility for achieving the objectives of the organization.(Hammad, 2006, p. 25)

2) Financial Control is the organizational plan and procedures relating to the maintenance of the assets of the entity and the extent of reliance on the financial statements by testing the accuracy of the accounting data and information (Masdor, 2010, p. 64)

3) The operational control includes a set of organizational and accounting procedures and means that aim to control the operations of the unit through the work of someone who is reviewing someone else's work to ensure the proper operation and prevent errors, and discover them after a short time ,and address them as soon as possible to avoid risks. (Levy \& William, 2004, pp881-905)

2.3 The Objectives of the Internal Control System (Lionel, C \& Gerard, V, pp. 41-42)

1) Control the bank.

2) Asset protection.

3) Ensure the quality and confidentiality of the information.

4) Encouraging work efficiently.

5) Encouraging adherence to policies and procedures.

\subsection{Components and Elements of the Internal Control System}

Administrative control is a component of the internal control system, which includes the presence of qualified personnel and a clear organizational structure that defines their powers. The second component is the Financial Control which includes financial risk assessment, reduction or mitigation of financial risks and compliance with financial procedures in accordance with international accounting laws, regulations and standards. Policies and procedures adopted by the Bank and strictly applied during day-to-day operations are considered as control activities which represent operational control and at the same time the Third component. All of these require an effective monitoring system to be implemented and followed up by a qualified team (Whittington, 2009, pp.72-92).

2.5 Objectives of the Internal Control System (Seventh, 2011, pp. 103-117)

1) The efficiency of the Bank's internal operations.

2) Reliability of financial reports issued by the bank.

3) Compliance and harmonization of the policies and procedures of the Bank's operations with the internal legislation issued by the Bank or issued locally by the government or issued globally.

\subsection{Challenges to the Internal Control System}

The availability of the internal control system does not mean the elimination of all risks and administrative corruption and the challenges facing the bank, but it is expected that there will be some abuses due to many reasons, including conflicting interests of the bank owner and managers, leading to some managers trying to circumvent the policies of the Bank to achieve their personal interests. It is supposed to be difficult for two or more people to collude with accounting or operation records. If collusion occurs, the internal control system cannot be relied upon to prevent theft, irregularities, fraud and personal interests. Challenges may arise due to error, forgetfulness, neglect, mental disturbance or misunderstanding of instructions to be applied, circumvention and collusion between parties inside or outside the bank. The cost of establishing a control system may exceed the benefits of the application of such system (Thomasohnki, 1989, pp. 372-373).

2.7 Competition Is the Struggle between Producers Who Offer Similar Products on the Market (Jean, 1998, p. 33).

And levels of competition (Ahmad, p. 2,3) 
1) Price competition so that the price of the services of the bank competes the price of other banks.

2) Paying attention to quality and provide the best products and develop it.

3) Expanding the provision of services and products.

\subsection{Competitive Advantage}

The competitive advantage refers to the Bank's ability to formulate and implement strategies that make it in a better position in comparison to other banks and compete through better utilization of the Bank's operations, financial and regulatory capabilities (Abu Bakr, 2007).

The most important elements of the competitive advantage of the bank is cost and then profits, threats and risks facing the work of the bank (Korankye, 2013).

The quality of the services provided supports high levels of competitiveness, enables them to meet the challenges, improve productivity, maintain the Bank's position in the market and ensure its business continuity and progress (Ware, 2014).

\subsection{The Relationship between Internal Control and the Competitive Advantage of the Bank}

The internal control reached by the researchers is a team that ensures that all employees of the Bank's departments comply with all procedures and policies related to their duties, whether administrative, financial or operations. In the event of errors, the reasons must be identified and addressed to achieve the desired goals and reduce the risks which face the bank and then get the highest performance in order to increase the level of competitive advantage of the bank.

\section{Methodology}

The study will apply the analytical descriptive approach to identify the theoretical aspects of the subject of the study. The study will be based on the theoretical aspect and the review of previous relevant studies. The field study will be applied for data acquisition, study and statistical analysis to show the role of internal control on the competitive advantage of the bank. Therefore, 137 questionnaires were distributed 106 of which, representing $77 \%$,were kept, to represent the sample of the study.31 questionnaires were excluded, 12 of which were not received, while 19 were incomplete.

\subsection{Data Collection Tools Were Obtained from Two Sources}

1) Books, periodicals, university thesis and related researches.

2) The questionnaire by virtue of my work for 24 years in banking sector, I know trustful colleagues what helped me to distribute questionnaires and retrieve as many as possible of them, either by e-mail, by direct contact or by phone calls. The questionnaire contained two parts:

a) Is dedicated for personal data of the sample. The details are attached to the study.

b) Discusses the hypotheses of the study where each hypothesis includes eight paragraphs as follows:

1) Administrative Control, contains (8) paragraphs.

2 ) Financial Control, contains (8) paragraphs.

3) Operational Control, contains (8) paragraphs.

4) The competitive advantage of the bank contains (8) paragraphs.

\subsection{Validity of the Questionnaire}

Before the distribution of the questionnaire, it was reviewed by a group of experts at the Faculty of Business at Tafila Technical University

Specialists in finance and economics to ensure the validity of the construction of the questionnaire in terms of accuracy of the wording and the statistical appropriateness of answer options to identify the problem of research and methodology.

\subsection{Statistical and Standard Tools Used}

The study tool used the Likert Scale, where the responses to the questionnaire were (strongly agree, agree, neutral, disagree, strongly disagree), and such options took the graduate numbers $(5,4,3,2,1)$ respectively. In order to interpret the responses of the study sample, three levels were relied upon: low, medium, and high, meaning that:

Low level: mean equals (1-2.3) 
Medium level: mean equals (2.4-3.5)

High level: mean equals (3.6-5)

\subsection{Reliability Test of the Study Tool}

The internal consistency was calculated using the Cronbach's Alpha, which is statistically acceptable if it is greater than 0.6 , and the higher this value is the higher stability of the study tool is. Internal consistency is illustrated through the statistical results attached to the study including:

1) Dimensions of the internal control system

Table 1. Averages, Standard Deviation, and Materiality for independent variables

Source: Authors.

\begin{tabular}{lll}
\hline & \multicolumn{2}{l}{ Statistic Data } \\
\cline { 2 - 3 } Variable & \# of questions & Cronbach's Alpha \\
\hline Administrative Control & 8 & 0.970 \\
Financial Control & 8 & 0.986 \\
Operational Control & 8 & 0.975 \\
Total & 24 & 0.971 \\
\hline
\end{tabular}

Table 1 shows that the Cronbach's Alpha values for the independent variables ranged between $(0.970$ - 0.986), in addition to that the value of Cronbach's Alpha of all the combined paragraphs was (0.971). Therefore, all values were greater than (0.6). This indicates that there is consistency between the paragraphs of the study tool, also reliability of the study tool what makes it reliable for statistical analysis.

2)with respect to the Bank's competitive advantage, the Cronbach's Alpha was 0.971, which is greater than 0.6, indicating the reliability of the study tool for statistical analysis.

\subsection{Statistical Analysis}

Table 2. Gender, Age, Scientific Qualification and Experience for sample

\begin{tabular}{llll}
\hline Variable & Category & Frequency & $\%$ \\
\hline Gender & Male & 89 & 84 \\
& Female & 17 & 16 \\
\cline { 2 - 4 } Age & Less than 25 years & 6 & 5.7 \\
& $25-35$ years & 24 & 22.6 \\
& $36-45$ years & 52 & 49.1 \\
Qualification & Greater than 45 years & 24 & 22.6 \\
\cline { 2 - 4 } & Diploma and less & 0 & 0 \\
& Beglories & 92 & 86.8 \\
& master & 9 & 8.5 \\
Experience & Doctorate & 5 & 4.7 \\
\cline { 2 - 4 } & Less than 5years & 4 & 3.8 \\
& 5-10 years & 38 & 35.8 \\
& $11-15$ years & 48 & 45.3 \\
& Greater than 15 years & 16 & 15.1 \\
\hline
\end{tabular}

Source: Authors.

The table above shows that males represent $84 \%$ of the study sample. The reason is that the efficiency of men in control is higher than that of females. As for age, it is noted that the age group (35 years - less than 45 years) (49.1\%) is the largest group. Also, the age group (less than 25 years) is the lowest (5.7\%). This corresponds to the paragraph "The control function needs to attract the older age group of young people who are rational in decision making." As for the academic qualification, the concentration of the sample was in the bachelor category which represents $86.8 \%$. In terms of experience, it is noted that the category (10 years - less than 15 years) is the largest and this corresponds to the requirements of the internal control career in the banks. 


\subsection{Analysis of the Study Questions}

Table 3. The arithmetical averages, standard deviations and the relative importance of the internal control questions

\begin{tabular}{|c|c|c|c|c|c|c|}
\hline Variables & $\#$ & Statement & rage & S.D & Order & Materiality \\
\hline & 1 & $\begin{array}{l}\text { The Department is keen to provide job descriptions } \\
\text { for each employee }\end{array}$ & 35 & 1.473 & 4 & high \\
\hline & 2 & $\begin{array}{l}\text { The administration is committed to passing all } \\
\text { circulars on all employees }\end{array}$ & 54 & 1.490 & 2 & high \\
\hline & 3 & $\begin{array}{l}\text { The administration shall ensure that the employee } \\
\text { performs the decisions according to the } \\
\text { instructions }\end{array}$ & 73 & 1.560 & 1 & high \\
\hline administrative & 4 & $\begin{array}{l}\text { Periodic review of the administrative work by a } \\
\text { specialized team }\end{array}$ & 70 & 1.637 & 3 & high \\
\hline \multirow[t]{8}{*}{ Control } & 5 & $\begin{array}{l}\text { Deviations in administrative work are identified } \\
\text { and processed }\end{array}$ & 30 & 1.686 & 6 & high \\
\hline & 6 & $\begin{array}{l}\text { Holds seminars and conferences to clarify what is } \\
\text { happening in the administrative field }\end{array}$ & 25 & 1.707 & 8 & medium \\
\hline & 7 & $\begin{array}{l}\text { The Bank is committed to implementing the } \\
\text { agreements concluded with others in a timely } \\
\text { manner }\end{array}$ & 34 & 1.762 & 7 & medium \\
\hline & 8 & $\begin{array}{l}\text { The bank cares about customer complaints and } \\
\text { work to resolve them urgently }\end{array}$ & 99 & 1.569 & 5 & high \\
\hline & & the scale & 35 & 1.466 & & high \\
\hline & 9 & $\begin{array}{l}\text { The control department ensures that the various } \\
\text { accounting processes are applied in accordance } \\
\text { with the Bank's instructions and policies }\end{array}$ & 23 & 1.634 & 4 & high \\
\hline & 10 & $\begin{array}{l}\text { The presence of an efficient team in auditing the } \\
\text { executed financial movements }\end{array}$ & 32 & 1.621 & 3 & high \\
\hline & 11 & $\begin{array}{l}\text { The Bank has the ability to respond quickly to } \\
\text { changes required in accounting standards. }\end{array}$ & 35 & 1.632 & 6 & high \\
\hline Financial & 12 & $\begin{array}{l}\text { Detect accounting mistakes first - hand and find } \\
\text { out the reasons }\end{array}$ & 35 & 1.632 & 6 & high \\
\hline \multirow[t]{8}{*}{ Control } & 13 & $\begin{array}{l}\text { The Bank uses the resources available } \\
\text { economically and rationally }\end{array}$ & 50 & 1.638 & 1 & high \\
\hline & 14 & $\begin{array}{l}\text { The Bank uses research \& development to } \\
\text { modernize its banking operations to achieve its } \\
\text { financial objectives at the lowest cost }\end{array}$ & 13 & 1.654 & 5 & high \\
\hline & 15 & $\begin{array}{l}\text { The Bank is keen to maximize shareholders' profits } \\
\text { and protect the Bank's assets }\end{array}$ & 12 & 1.663 & 2 & high \\
\hline & 16 & Documentation of controls and recommendations & 12 & 1.611 & 2 & high \\
\hline & & the scale & 23 & 1.564 & & high \\
\hline & 17 & $\begin{array}{l}\text { The control department ensures that operations } \\
\text { follow the instructions and policies of the Bank }\end{array}$ & 15 & 1.610 & 2 & high \\
\hline & 18 & $\begin{array}{l}\text { The Bank uses a variety of methods to improve } \\
\text { quality }\end{array}$ & 26 & 1.630 & 4 & high \\
\hline & 19 & $\begin{array}{l}\text { Bank employees have multiple skills that enable } \\
\text { them to perform more than one job or job. }\end{array}$ & 36 & 1.652 & 3 & high \\
\hline Operational & 20 & $\begin{array}{l}\text { The Bank seeks to continuously reduce the costs of } \\
\text { banking operations }\end{array}$ & 78 & 1.587 & 5 & high \\
\hline \multirow[t]{4}{*}{ Control } & 21 & $\begin{array}{l}\text { Address errors if any and address their causes as } \\
\text { soon as possible }\end{array}$ & 54 & 1.631 & 1 & high \\
\hline & 22 & $\begin{array}{l}\text { Training courses are held for staff to develop their } \\
\text { performance }\end{array}$ & 50 & 1.639 & 6 & high \\
\hline & 23 & $\begin{array}{l}\text { Directing severe penalties for violators of policies } \\
\text { and procedures }\end{array}$ & 12 & 1.674 & 7 & high \\
\hline & 24 & $\begin{array}{l}\text { The Bank is committed to deadlines for delivery of } \\
\text { services to customers }\end{array}$ & 54 & 1.601 & 1 & high \\
\hline
\end{tabular}

Source: Authors.

The table shows that the level of the general measure of administrative control paragraphs is average with a mean of (3.5849), and a standard deviation of (1.46624). The paragraph "the management makes sure that the 
employee duly implements the orders according to instructions" ranked first with a mean of (3.7925), and a high relative significance, While the paragraph "Training courses for employees are held to develop staff" ranked last with a mean of (3.4340), and an average relative significance.

As for the level of the general measure of the financial control paragraphs, it was very high, with a mean of 3.6226 and a standard deviation of 1.5642. The paragraph "Treatment of errors, if any, and treatment of causes as soon as possible" has ranked first with a mean of (3.6604), and a high relative significance, while the paragraphs "Revision of accounting operations periodically and adjusted to keep pace with the development of accounting standards" and "the detection of accounting errors on an ongoing basis and find the reasons" have ranked last with a mean of (3.5849), and an average relative significance. The level of the general measure of operational control paragraphs was high with a mean of (3.7170), and a standard deviation of (1.50399). The paragraphs "Documentation of operational control processes and their recommendations" and " Treatment of errors, if any, and treatment of causes as soon as possible " have ranked first with a mean of (3.7642), and a high relative significance, while the paragraph "Application of severe penalties for violators of policies and procedures" ranked last with a mean of (3.6415), and an average relative significance.

Table 4. Averages, Standard Deviation, and Materiality for independent variables

\begin{tabular}{llll}
\hline & & Statistic & \\
\cline { 3 - 4 } Variable & Average & S. Deviation & Materiality \\
\hline Administrative Control & 3.585 & 1.466 & High \\
Financial Control & 3.623 & 1.564 & High \\
Operational Control & 3.717 & 1.504 & High \\
Total & 3.642 & 1.512 & High \\
\hline
\end{tabular}

The results of Table indicate that the level of the measure of the internal control system had a high relative significance, with a mean of (3.6415) and a standard deviation of (1.51148). The table also shows that the operational control dimension ranked first, with a standard deviation of (1.50399), and with a high relative significance. Administrative control dimension has ranked last with a mean of (3.5849), with a standard deviation of (1.46624), and a an average relative significance

\subsection{Competitive Advantage of the Bank}

Table 5. The arithmetical averages, standard deviations and the relative importance of the internal control questions

\begin{tabular}{|c|c|c|c|c|c|c|}
\hline & \# & Statement & Averages & S.D & Order & Materiality \\
\hline & 1 & $\begin{array}{l}\text { There will be seminars to clarify what is happening in the local and } \\
\text { international banking arena and the dangers of not knowing it }\end{array}$ & 3.877 & 1.485 & 1 & high \\
\hline & 2 & $\begin{array}{l}\text { The Bank's mission and objectives are consistent with the objectives and } \\
\text { values of internal control in the banking sector }\end{array}$ & 3.783 & 1.480 & 6 & high \\
\hline Competitive & 3 & $\begin{array}{l}\text { The Bank is equipped with panels to facilitate customer interaction with } \\
\text { the employee concerned }\end{array}$ & 3.793 & 1.596 & 5 & high \\
\hline \multirow{7}{*}{$\begin{array}{l}\text { advantage of } \\
\text { the } \\
\text { bank }\end{array}$} & 4 & The interior and exterior design of the bank is practical and attractive & 3.783 & 1.562 & & \\
\hline & & & & & 6 & high \\
\hline & 5 & $\begin{array}{l}\text { Providing the service accurately and as soon as possible and acceptable } \\
\text { to the customers with the bank }\end{array}$ & 3.840 & 1.550 & 2 & high \\
\hline & 6 & Bank employees show interest in the client and solve their problems & 3.774 & 1.605 & 7 & high \\
\hline & 7 & The behavior of the Bank's staff gives customers a sense of confidence & 3.811 & 1.598 & 4 & high \\
\hline & 8 & The Bank is keen to respond to customer complaints after confirmation & 3.830 & 1.489 & 3 & high \\
\hline & & the scale & 3.764 & 1.425 & & high \\
\hline
\end{tabular}

Source: Authors.

Table 5 shows that the level of the general measure of the interbank competition paragraphs was high, with a mean of (3.7642) and a standard deviation of (1.42463). The paragraph "The Bank holds seminars to clarify what is new in the field of domestic and international banking arena and the risks of not knowing it" ranked first with 
a mean of (3.8774), and a high relative significance, while the paragraph "Bank employees take care of customers and solve their problems" has ranked last with a mean of (3.7736), and a high relative significance.

\subsection{Test the Validity of Data for Statistical Analysis}

To test the appropriateness of the study data for linear regression analysis, multicollinearity test was carried out using Pearson correlation coefficients to detect the multiple linear correlation problems between the independent variables of the study.

Table 6. The matrix of correlation for the independent variables

\begin{tabular}{llll}
\hline Variable & Administrative Control & Financial Control & Operational Control \\
\hline Administrative Control & 1 & & \\
Financial Control & -0.382 & 1 & \\
Operational Control & -0.400 & -0.282 & 1 \\
\hline
\end{tabular}

$(* *)$ Statistically significant at $(\alpha \leq 0.01)(*)$ statistically significant at $(\alpha \leq 0.05)$.

Source: Authors.

The table shows the correlation matrix for the variables of the study, where the highest correlation between the independent variables between the two dimensions (administrative control) and (operational control) was (-400), while the correlation coefficient values between the other independent variables were lower. This indicates that there is no linear correlation between the independent variables, where the correlation that exceeds $(0.80)$ is an indication of the existence of this problem, so we can say that the sample is free of the problem of high and medium linear correlation (Guajarati, op. Cit., p.359).

Table 7. Multicollinearity test results between independent variables

\begin{tabular}{ll}
\hline Variable & VIP \\
\hline Administrative Control & 1.741 \\
Financial Control & 1.588 \\
Operational Control & 1.616 \\
\hline
\end{tabular}

Source: Authors.

In order to confirm the previous result, Variance Inflation Factor (VIP) was calculated, and the result was as in Table 7 where the values of the Variance Inflation Factor were all greater than 1) and less than (10), indicating that there was no multiple linear correlation problem between the variables of the study.

\section{Test of Hypotheses}

H01: There is no statistically significant effect at the level $(\alpha \leq 0.05)$ of internal control system (administrative control, financial control, operational control) on the competitive advantage of the bank.

The sub-hypotheses of main hypothesis are:

H01-1: There is no statistically significant effect at the level $(\alpha \leq 0.05)$ of the internal control system (administrative control) on the (competitive advantage of the bank).

H01-2: There is no statistically significant effect at the level $(\alpha \leq 0.05)$ of the internal control system (financial control) on the (competitive advantage of the bank).

H01-3: There is no statistically significant effect at the level $(\alpha \leq 0.05)$ of the internal control system (operational control) on the (competitive advantage of the bank). 
Table 8. Result of examining the effect of Internal Control (Administrative Control) on Competitive Advantage for Banks

\begin{tabular}{|c|c|c|c|c|c|c|c|c|c|}
\hline \multirow[b]{2}{*}{ Dependent variable } & \multirow[b]{2}{*}{$\begin{array}{l}\mathrm{R} \\
\text { Correlation } \\
\text { coefficient }\end{array}$} & \multirow[b]{2}{*}{$\begin{array}{l}\mathrm{R}^{2} \\
\text { Coefficient } \\
\text { determination }\end{array}$} & \multirow[b]{2}{*}{$\begin{array}{l}\text { calculated } \\
\text { F }\end{array}$} & \multirow[b]{2}{*}{$\begin{array}{l}\text { Sig } \\
\mathrm{F}^{*}\end{array}$} & \multicolumn{5}{|c|}{ Regression coefficient } \\
\hline & & & & & Statement & $\beta$ & $\begin{array}{l}\text { Standard } \\
\text { error }\end{array}$ & $\begin{array}{l}\text { calculated } \\
\mathrm{T}\end{array}$ & $\begin{array}{l}\text { Sig } \\
t^{*}\end{array}$ \\
\hline \multirow{2}{*}{$\begin{array}{l}\text { Competitive } \\
\text { Advantage for Banks }\end{array}$} & \multirow[t]{2}{*}{0.605} & \multirow[t]{2}{*}{0.366} & \multirow[t]{2}{*}{59.943} & \multirow[t]{2}{*}{0.000} & $\begin{array}{l}\text { Administrative } \\
\text { Control }\end{array}$ & 0.588 & 0.076 & 7.742 & 0.000 \\
\hline & & & & & Regression & 1.658 & 0.294 & 5.645 & 0.000 \\
\hline
\end{tabular}

$(*)$ The effect is statistically significant at $(\alpha \leq 0.01)$.

Source: Authors.

The results of Table 8 show that the effect of the independent variable (administrative control) on the dependent variable (the competitive advantage of the bank) is statistically significant. The calculated $\mathrm{F}$ value is (59.943) and the significance level is $(\mathrm{Sig} F=0.000)$ which is less than 0.05 , while $(r=0.605)$ which indicates the relationship between the two variables. The value of the coefficient of determination is $\left(\mathrm{r}^{2}=0.366\right)$ which indicates that $36.6 \%$ of the variance in the bank's competitive advantage can be explained by the variance in (administrative control), with all other variables remain constant.

The table of coefficients shows that the value of $\beta$ at administrative control dimension is (0 .588). ( $\beta$ ) Value indicates the positive effect of the administrative control on the competitive advantage of the bank, and that the value of $\mathrm{t}$ is 7.742 with a significance level of $(\mathrm{Sig}=0.000)$ indicating that the effect of this dimension is significant.

We therefore reject the first null hypothesis and accept the alternative hypothesis which stipulates that:

There is a statistically significant effect at the level $(\alpha \leq 0.05)$ of the internal control system (administrative control) on the (competitive advantage of the bank).

Table 9. The result of examining the effect of Internal Control (Financial Control) on Competitive Advantage for Banks

\begin{tabular}{|c|c|c|c|c|c|c|c|c|c|}
\hline \multirow[b]{2}{*}{ Dependent variable } & \multirow[b]{2}{*}{$\begin{array}{l}\mathrm{R} \\
\text { Correlation } \\
\text { coefficient }\end{array}$} & \multirow[b]{2}{*}{$\begin{array}{l}\mathrm{R}^{2} \\
\text { Coefficient } \\
\text { determination }\end{array}$} & \multirow[b]{2}{*}{$\begin{array}{l}\text { calculated } \\
\text { F }\end{array}$} & \multirow[b]{2}{*}{$\begin{array}{l}\text { Sig } \\
\mathrm{F}^{*}\end{array}$} & \multicolumn{5}{|c|}{ Regression coefficient } \\
\hline & & & & & Statement & $\beta$ & $\begin{array}{l}\text { Standard } \\
\text { error }\end{array}$ & $\begin{array}{l}\text { calculated } \\
\mathrm{T}\end{array}$ & $\begin{array}{l}\text { Sig } \\
\mathrm{t}^{*}\end{array}$ \\
\hline \multirow{2}{*}{$\begin{array}{l}\text { Competitive } \\
\text { Advantage for Banks }\end{array}$} & \multirow[t]{2}{*}{0.635} & \multirow[t]{2}{*}{0.403} & \multirow[t]{2}{*}{70.250} & \multirow[t]{2}{*}{0.000} & $\begin{array}{l}\text { Financial } \\
\text { Control }\end{array}$ & 0.578 & 0.069 & 8.382 & 0.000 \\
\hline & & & & & Regression & 1.669 & 0.272 & 6.136 & 0.000 \\
\hline
\end{tabular}

(*) The effect is statistically significant at $(\alpha \leq 0.01)$.

Source: Authors.

The results of Table 9 show that the effect of the independent variable (financial control) on the dependent variable (the competitive advantage of the bank) is statistically significant, where the calculated $\mathrm{F}$ value is (70.250) and the significance level ( $\operatorname{Sig} F=0.000)$ which is less than $(0.05)$, while the coefficient of correlation $(\mathrm{r}=0.635)$ which indicates the relationship between the two variables. In addition, the value of the coefficient of determination is $\left(\mathrm{r}^{2}=0.403\right)$ indicating that $40.3 \%$ of the variance in the bank's competitive advantage can be explained by the variance in (financial control), with all other variables remain constant.

The table of coefficients shows that the value of $\beta$ at financial control dimension is $(0.588)$. ( $\beta$ ) Value indicates the positive effect of the financial control on the competitive advantage of the bank, and that the value of $t$ is 8.382 with a significance level of $(\mathrm{Sig}=0.000)$ indicating that the effect of this dimension is significant.

Accordingly, we reject the second null hypothesis and accept the alternative hypothesis which stipulates that:

There is a statistically significant effect at the level $(\alpha \leq 0.05)$ of the internal control system (financial control) on the (competitive advantage of the bank). 
Table 10. Result of examining the effect of Internal Control (Operational Control) on Competitive Advantage for Banks

\begin{tabular}{|c|c|c|c|c|c|c|c|c|c|c|}
\hline \multirow[b]{2}{*}{ Dependent variable } & \multirow[b]{2}{*}{$\begin{array}{l}\mathrm{R} \\
\text { Correlation } \\
\text { coefficient }\end{array}$} & \multirow[b]{2}{*}{$\begin{array}{l}\mathrm{R}^{2} \\
\text { Coefficient } \\
\text { determination }\end{array}$} & \multirow[b]{2}{*}{ of } & \multirow[b]{2}{*}{$\begin{array}{l}\text { calculated } \\
\text { F }\end{array}$} & \multirow[b]{2}{*}{$\begin{array}{l}\text { Sig } \\
\mathrm{F}^{*}\end{array}$} & \multicolumn{5}{|c|}{ Regression coefficient } \\
\hline & & & & & & Statement & $\beta$ & $\begin{array}{l}\text { Standard } \\
\text { error }\end{array}$ & $\begin{array}{l}\text { calculated } \\
\mathrm{T}\end{array}$ & $\begin{array}{l}\text { Sig } \\
t^{*}\end{array}$ \\
\hline \multirow{2}{*}{$\begin{array}{l}\text { Competitive } \\
\text { Advantage for Banks }\end{array}$} & \multirow[t]{2}{*}{0.591} & \multirow[t]{2}{*}{0.349} & \multirow{2}{*}{\multicolumn{2}{|c|}{55.776}} & \multirow[t]{2}{*}{0.000} & $\begin{array}{l}\text { Operational } \\
\text { Control }\end{array}$ & 0.560 & 0.075 & 7.468 & 0.000 \\
\hline & & & & & & Regression & 1.684 & 0.300 & 5.608 & 0.000 \\
\hline
\end{tabular}

(*) The effect is statistically significant at $(\alpha \leq 0.01)$.

Source: Authors.

The results of Table 10 show that the effect of the independent variable (operational control) on the dependent variable (the competitive advantage of the bank) is statistically significant, where the calculated $\mathrm{F}$ value is (55.776) and the significance level ( $\operatorname{Sig} F=0.000)$ which is less than (0.05), while the coefficient of correlation $(\mathrm{r}=0.591)$ which indicates the relationship between the two variables. In addition, the value of the coefficient of determination is $\left(\mathrm{r}^{2}=0.349\right)$ indicating that $34.9 \%$ of the variance in the bank's competitive advantage can be explained by the variance in (operational control), with all other variables remain constant.

The table of coefficients shows that the value of $\beta$ at operational control dimension is (-.560 0). ( $\beta$ ) Value indicates the positive effect of the operational control on the competitive advantage of the bank, and that the value of $\mathrm{t}$ is 7.468 with a significance level of $(\mathrm{Sig}=0.000)$ indicating that the effect of this dimension is significant.

Accordingly, we reject the third null hypothesis and accept the alternative hypothesis which stipulates that:

There is a statistically significant effect at the level $(\alpha \leq 0.05)$ of the internal control system (operational control) on the (competitive advantage of the bank).

In order to test the main hypothesis multiple linear regression analysis was applied.

Table 11. The result of examining the effect of internal control (administrative control, financial control, operational control) on competitive advantage for banks

\begin{tabular}{|c|c|c|c|c|c|c|c|c|c|}
\hline \multirow[b]{2}{*}{ Dependent variable } & \multirow[b]{2}{*}{$\begin{array}{l}\mathrm{R} \\
\text { correlation } \\
\text { coefficient }\end{array}$} & \multirow[b]{2}{*}{$\begin{array}{l}\mathrm{R}^{2} \\
\text { coefficient } \\
\text { determination }\end{array}$} & \multirow[b]{2}{*}{ of $\begin{array}{l}\text { calculated } \\
F\end{array}$} & \multirow{2}{*}{$\begin{array}{l}\text { Sig } \\
\mathrm{F}^{*}\end{array}$} & \multicolumn{5}{|c|}{ Regression coefficient } \\
\hline & & & & & Statement & $\beta$ & $\begin{array}{l}\text { Standard } \\
\text { error }\end{array}$ & $\begin{array}{l}\text { calculated } \\
\mathrm{T}\end{array}$ & $\begin{array}{l}\text { Sig } \\
\mathrm{t}^{*}\end{array}$ \\
\hline \multirow{4}{*}{$\begin{array}{l}\text { Competitive } \\
\text { Advantage for Banks }\end{array}$} & \multirow{4}{*}{0.732} & \multirow{4}{*}{0.535} & \multirow{4}{*}{39.186} & \multirow{4}{*}{0.000} & $\begin{array}{l}\text { Administrative } \\
\text { Control }\end{array}$ & 0.246 & 0.087 & 2.844 & 0.005 \\
\hline & & & & & Financial Control & 0.326 & 0.077 & 4.210 & 0.000 \\
\hline & & & & & $\begin{array}{l}\text { Operational } \\
\text { Control }\end{array}$ & 0.248 & 0.081 & 3.057 & 0.003 \\
\hline & & & & & Regression & 0.777 & 0.294 & 2.648 & 0.009 \\
\hline
\end{tabular}

$(*)$ The effect is statistically significant at $(\alpha \leq 0.01)$.

Source: Authors.

The results of the table show that the effect of the independent variables (administrative, financial and operational control) on the dependent variable (the competitive advantage of the bank) is statistically significant, where the calculated $F$ value is (39.186) and the significance level (Sig F =0.000) which is less than (0.05), while the coefficient of correlation $(r=0.732)$ which indicates the relationship between the two variables. In addition, the value of the coefficient of determination is $\left(\mathrm{r}^{2}=0.535\right)$ indicating that $53.5 \%$ of the variance in the bank's competitive advantage can be explained by the variance in (administrative, financial and operational control), with all other variables remain constant.

The table of coefficients shows that the value of $\beta$ at operational control dimension is $(0.246)$. ( $\beta$ ) Value indicates the positive effect of the administrative control on the competitive advantage of the bank, and that the value of $t$ 
is 2.844 with a significance level of $(\mathrm{Sig}=0.005)$ indicating that the effect of this dimension is significant. The value of $\beta$ at financial control dimension is $(=\beta 326)$. ( $\beta$ ) Value indicates the positive effect of the financial control on the competitive advantage of the bank, and that the value of $t$ is 4.210 with a significance level of (Sig $=0.000$ ) indicating that the effect of this dimension is significant. The value of $\beta$ at operational control dimension is $(\beta=326)$. ( $\beta$ ) Value indicates the positive effect of the operational control on the competitive advantage of the bank, and that the value of $\mathrm{t}$ is 3.057 with a significance level of $(\mathrm{Sig}=0.003)$.

Accordingly, we reject the main null hypothesis and accept the alternative hypothesis which stipulates that:

There is a statistically significant effect at the level $(\alpha \leq 0.05)$ of the internal control system ((administrative, financial and operational control)) on the (competitive advantage of the bank).

\subsection{Discussion of the results of the hypotheses of the study}

Based on the results of the previous statistical tests listed in tables $(8,9,10,11)$, there was a statistically significant positive effect at significance level (00.05) of the internal control dimensions - whether individually or collectively - on the competitive advantage of the bank. The study will rely on the main hypothesis in the results and recommendations. This is because the value of $\left(\mathrm{r}^{2}\right)$ of the main hypothesis is greater than the values of $\left(\mathrm{r}^{2}\right)$ of the sub-hypotheses. This means that the percentage of change in the competitive advantage of the bank explained by the change in the dimensions of internal control (administrative, Financial, and operational) of the main hypothesis is greater than the values of the sub-hypotheses, but the other statistical characteristics of hypotheses are similar.

\section{Results and Recommendations}

\subsection{Theoretical Results}

1) The concept of competitive advantage at the bank is broad and relative, and differs from non-banking sectors .Also, the degree of competitive advantage at the bank increases in the following cases:

a) Decline of risks facing the Bank.

b) The high volume of profit.

c) Level of quality of services provided by the bank.

d) Increasing staff efficiency and performance.

2) Achieving a higher level of internal control will reduce the risks facing the Bank, increase the volume of profits, increase the quality of services provided by the bank, increase the efficiency of employees and improve their performance and thus increase the competitive advantage of the bank.

\subsection{Statistical Results}

1) The results of the hypotheses test showed that the administrative control has a positive effect on the competitive advantage of the bank. Administrative control preserves the bank's assets, management development and increases the level of the performance of the employees, thus increasing the competitive advantage of the bank.

2) The results of the hypotheses test showed that financial control had a positive effect on the competitive advantage of the bank. Financial control reduces risks and increases profits, thus increasing the competitive advantage of the bank.

3) The results of the hypotheses test showed that operational control had a significant positive effect on the competitive advantage of the bank. Operational control reduces the operational risks and losses and increases the quality of the services provided, thus increasing the competitive advantage of the bank.

4) The results of the hypothesis test showed that internal control (administrative, financial, operational control) collectively had a significant positive effect on the competitive advantage of the Bank. These results do not contradict the previous studies that dealt with the subject of control or the subject of competition separately because there was no study that dealt with the whole subject (the impact of internal control on the competitive advantage of the bank).

\subsection{Recommendations}

Based on the findings of the current study, the following recommendations were proposed:

1) It is necessary to establish a department concerned with internal control in all its dimensions, and to activate its role through being the reference of the manager of the internal audit department, the manager of audit department or the general manager of the bank. 
2) The internal control department should be informed about the opinions, suggestions and complaints of the bank's customers, and to address the reasons for such complains and to resolve all the problems mentioned in the report of the internal control officer firsthand before the aggravation of the problem to reduce the financial and operational risks that may result from not resolving them.

3) There is a need to raise the efficiency of internal control staff through providing them with specialized training courses in internal control work, and the bank's work in general.

4) Updating the internal control system in line with the standards of control and auditing in banking sector.

\section{Acknowledgments}

Acknowledge colleagues who assisted in conducting the study or critiquing the manuscript. In this paragraph, authors contributed equally to the study. End this paragraph with thanks for personal assistance, such as in manuscript preparation.

\section{References}

Abdul, R., \& Mohamed, O. (2010). Principles of Internal Auditing and Control, I2, Dar Al Kutab for Printing and Publishing, University of Mosul, Iraq.

Abu Bakr, M. (2007). Human Resources: An Introduction to Competitive Advantage, Al-Dar Al-Jami'yah, and Alexandria, Egypt.

Ahmed, Z. (nd.). Strategic Alliance as an Option for the Algerian Foundation, unpublished PhD thesis, Faculty of Economics and Management Sciences, University of Algiers, Algeria.

Al-Jabiri, M. A. (2014). Evaluation of The Role of Internal Auditor in Improving The Internal Control System of Accounting Information Systems in Insurance Companies Operating in Yemen. Arab Academy for Banking and Financial Sciences, Sana'a, Yemen.

Al-Na'sani, A. Y. (2010). The Extent to Which Islamic Banks Apply Internal Control: An Applied Study on Banks Operating in Hadramout, Journal of Administrative Sciences, 1(2), 79-105.

Al-Rabidi, M. A. (2012). Evaluation of the Control System of the Establishments That Use Information Technology: A Field Study in the Yemeni Audit Offices. Arab Journal of Accounting, 10. https://doi.org/10.12785/aja/150103

Al-Sha'ibi, M. A. (2011). Adaptation of Internal Control Systems with the Use of Information Technology and its Impact on the Reliability of Financial Statements: An Empirical Study on Libyan Commercial Banks. Unpublished MA thesis, Middle East University, Amman, Jordan.

Al-Sobou', S. (2011). The Effect of Internal Control Systems in accordance with the COSO Framework on Control Objectives: Case study of Jordanian Industrial Companies. Journal of Administrative Studies, 38(1).

Al-Wardat, K. A. (2006). Internal Audit between Theory and Practice in accordance with Internal Auditing Standards. Dar Al Warraq Publishing and Distribution, Amman, Jordan.

Diagle, R. J., Kizirian, T., \& Sneathen, D. (2005). System controls reliability \& Assessment efforts. International journal of auditing, 9(1). https://doi.org/10.1111/j.1099-1123.2005.00103.x

Hammad, A. I. (2006). Financial Control in the Public Sector. Dar Juhayna Publishing and Distribution, Amman, Jordan.

Hildani, A., \& Ajeeb, A. G. (2010). The Role of Internal Control under the Electronic Accounting Information System. Journal of Human Sciences, 7(45), 1-39.

Jean- Claude, T. (1998). Stratégieindustrielle (2nd ed.). Paris, France.

Korankye, A. (2013). Total Quality Management (TQM): A Source of Competitive Advantage. A Comparative Study of Manufacturing and Service Firms in Ghana. International Journal of Asian Social Science, 3(6), 1293-1305.

Levy, P. E., \& William, J. R. (2004). The social context of performance appraisal: A review and framework for the future. Journal of management, 30. https://doi.org/10.1016/j.jm.2004.06.005

Lionel. C., \& Gerard. V. (1992). Audit et control interne, aspects financiers, opération et stratégiques (4th ed.). Dalloze; Paris.

Masdor, F. (2010). Banking Control between Islamic Banks and Traditional Banks, a study submitted to the International Scientific Conference on Financial Services and Risk Management in Islamic Banks. Farhat 
Abbas University, Setif, Algeria.

Mosleh, N. A. A. (2007). The Impact of Computer Usage on Internal Control Systems in Banks Operating in Gaza Strip. Unpublished MA, Islamic University, Gaza, Palestine.

Thomas, W., \& Emerson, H. (1989). Auditing: theory and practice, Arabization and references by Ahmad Hajaj and Kamal al-Din Saeed. Dar al-Marikh, Riyadh, Saudi Arabia.

Tuttle, B., \& Vandervelde, S. (2006). An empirical examination of Cubit as an internal control frame work for information technology. International Journal of Accounting Information Systems, 240-263. https://doi.org/10.1016/j.accinf.2007.09.001

Ware, E. (2014). Investigate the Benefit Practice of Total Quality Management as Competitive Advantage in Corporate Institution: A Case Study of Cocoa-Cola Bottling Company Ghana Ltd. Research Journal of Finance and Accounting, 5(23), 99-97.

Whittington, R. (2009). New Audit Documentation Requirement: SAS96 Raise the Bar for Audit Documentation, Adding Specific Requirement in Several Areas. Journal of Accountancy, 65(3).

\section{Copyrights}

Copyright for this article is retained by the author(s), with first publication rights granted to the journal.

This is an open-access article distributed under the terms and conditions of the Creative Commons Attribution license (http://creativecommons.org/licenses/by/4.0/). 